\title{
What does it mean when people call a place a shithole? Understanding a discourse of denigration in the United Kingdom and the Republic of Ireland.
}

\author{
BUTLER, A., SCHAFRAN, A. and CARPENTER, G.
}

This is the peer reviewed version of the following article: BUTLER, A., SCHAFRAN, A. and CARPENTER, G. 2018. What does it mean when people call a place a shithole? Understanding a discourse of denigration in the United Kingdom and the Republic of Ireland. Transactions of the institute of British Geographers [online], 43(3), pages 496-510, which has been published in final form at https://doi.org/10.1111/tran.12247. This article may be used for non-commercial purposes in accordance with Wiley Terms and Conditions for Use of Self-Archived Versions. This article may not be enhanced, enriched or otherwise transformed into a derivative work, without express permission from Wiley or by statutory rights under applicable legislation. Copyright notices must not be removed, obscured or modified. The article must be linked to Wiley's version of record on Wiley Online Library and any embedding, framing or otherwise making available the article or pages thereof by third parties from platforms, services and websites other than Wiley Online Library must be prohibited. 


\section{What does it mean when people call a place a shithole?: Understanding a discourse of denigration in the United Kingdom and the Republic of Ireland}

Alice Butler*, Alex Schafran and Georgina Carpenter

School of Geography

University of Leeds

\section{Introduction}

Territorial stigmatization has emerged as a means of understanding place-based stigma. In a 2015 review of the literature on territorial stigmatization, Tom Slater (2017) categorized the existing literature according to four themes: the political activation of territorial stigma; neighbourhood investment and disinvestment; residents' strategies for managing territorial stigmatization; and the production of territorial stigma. While Slater provides evidence that researchers have investigated the first three of these themes, "very few studies have taken up the challenge of tracing the production of territorial stigmatization (Slater 2017, 6)."

This paper attempts to meet Slater's call for greater understanding of the production of territorial stigma. In this study, we take 'production' to mean the formation of denigration and stigmatization, the most basic act of stigmatizing through language. We seek to understand which places are being stigmatized and by whom, and which criteria are used to judge whether a place is worthy of condemnation. As Slater has clarified, scholars have established how stigma is used, how it is coped with, and how it impacts policy and investment, but there remain gaps: we do not know about gender differences in the process of stigmatization nor what goes into someone making the decision to denigrate a place. Not enough is known to answer even the simple question: do people denigrate only other places or their own? The assumption would be that the former is true but, as this study shows, an important minority of stigmatizing behaviour is self-inflicted by residents. 
This paper is the first large-scale study of territorial stigma using data from Twitter users in the United Kingdom and Ireland. As explained in the methodology section below, we examined a sample of 2,076 individual tweets emanating from the UK and Ireland between December 2015 and May 2016 which contained the word "shithole" or used the hashtag '\#shithole'. User data enabled us to identify from where the Twitter user tweeted, the Twitter user's own location, the geography to which the tweet was referring, and the gender of the user. Using a process developed through rounds of discourse analysis developed from popular literature and online forums, we developed a set of codes which get at the meaning of each use of "shithole". Further, and more fundamentally geographic, we coded each tweet according to the relational geography of each tweet.

Through this approach, we have been able to see which types of place are being stigmatized, by whom, where specifically is being stigmatized, whether a place is being stigmatized by outsiders or by its own residents, and the criteria used to determine whether a place is to be denigrated. While the dominant discourses of denigration operationalized by the state and media are heavily present in the data, and at times even dominant themselves, we argue that there is a great need to listen beyond the dominant voices who speak about 'other' places from afar and who reinforce the majoritarian discourses of demographic and politico-economic difference. By only considering the majoritarian voices we risk not understanding the lived reality of stigma and the trend that we discover of stigmatizing one's own or personal geographies. While the same markers used by powerful actors seeking to divide and stigmatize are prevalent among the majority of Twitter users who produce and re-produce stigma about an 'other' place from a distance, the minoritarian voices ${ }^{1}$ often speak from within places and engage in a form of auto-stigmatization which appears as a means of coping or a desire to leave. 
We first provide a review of the literature on territorial stigma and touch briefly on the concept of abjection, better situating our study and making clear the logic behind our strategy. We explain our methodology, including our detailed coding mechanism. Next, we examine our findings, focusing first on the majoritarian findings, which generally conform to similar logics as when the discourse is used or reproduced by the state. Race, class, foreignness and the act of 'othering' feature prominently. We focus on the minoritarian voices within the dataset, on the aforementioned way in which gendered voices operationalize the notion of 'shithole' for different reasons than do those in power. The penultimate section suggests how a conceptualization of spatial abjection can allow us to understand these minoritarian voices and the desire to separate place from self-identity. We conclude with a summary of our findings and questions that our study raised, including whether national differences in territorial stigma noted by Wacquant (2008) transfer to individuals within those states. Is there a culture of placebased denigration in the UK and Ireland?

\section{Origins of territorial stigmatization and the discourse of denigration}

As coined by Wacquant, (Wacquant 1993; Wacquant 2007; Wacquant 2008; Wacquant, Slater and Pereira 2014), territorial stigmatization is situated at the intersection of space and place, particularly in the post-industrial era. Wacquant's naming and development of the concept with such a temporal hold joins a longer history of industrial stigma and negative reputation studies that often focused on slum or 'delinquent' areas of inner cities (Davie 1932; Firey 1945; Tucker 1966; Damer 1974; Gill 1977; Damer 1989). Wacquant's framing of territorial stigmatization was the result of a union of Goffman's work on stigma with Bourdieu's work on symbolic violence and group-making (Wacquant 2008, 7), explaining that territorial stigmatization becomes normalized as a result of the internalization of social and political power 
dynamics. The concept is described by Wacquant as "the powerful stigma attached to residence in the bounded and segregated spaces, the 'neighbourhoods of exile' to which the populations marginalised or condemned to be redundant by the post-Fordist reorganisation of the economy and state are increasingly being relegated" (Wacquant 1993, 369).

Wacquant's conceptualization of territorial stigmatization has a strong discursive element. He explains that stigmatized locations are "widely labelled as 'no-go areas', fearsome redoubts rife with crime, lawlessness and moral degeneracy where only the rejects of society could bear to dwell" (Wacquant 2008, 29), thereby highlighting that it is the 'labelling', the rumour, the reputation surrounding an area that enables and facilitates territorial stigmatization. Language, in this understanding, is being used "as a form of social practice" (Fairclough 1995, 7) that constructs and attaches reputations, stigmas and stereotypes to certain geographies and those who live there; the adhesiveness of such discourse cannot be underestimated (Gourlay 2007).

In line with Slater's categorization of the literature according to four themes (2017), we also note two distinct focuses that divide the literature. The first includes work that focuses on the role of the powerful producers and users of stigma including the state, policy, and media whose dominant voices construct stigmatized locations (see Devereux et al. 2011a; Devereux et al. 2011b; Gray and Mooney 2011; Kallin and Slater 2014; Kornberg 2016; Schultz Larsen 2013; Wacquant 1993; Wacquant 1996; Wacquant 2007; Wacquant 2008) The second strand of literature has a primary focus on the lived experience of residence in a stigmatized location (see Gourlay 2007; Holt and Wilkins 2014; Keene and Padilla 2010; Morris 2013; Rhodes 2012; Slater and Anderson 2011). Several studies attempt to bridge the divide by considering and comparing the different perceptions of place by residents in and neighbours of stigmatized locations (see Hastings 2004; Hastings and Dean 2003; Jensen and Christensen 2012; 
Permentier et al. 2008 and Rijnks and Strijker 2013). This focus-oriented distinction is one of the most important ways of understanding how the literature on territorial stigma has formed along the contours Slater (2017) discusses.

Literature in the first strand largely follows either a field-analytic approach detailed by Schultz Larsen (2013) that considers the roles of institutions and actors in positions of power, or a comparative ethnography and analysis as detailed by Wacquant $(1996 ; 2007 ; 2008)$ that compares the roles of states in applying and facilitating spatial smear (Schultz Larsen, 2013). For Wacquant, the emergence of territorial stigma as a phenomenon is part of a larger advanced marginality that is the result of politico-economic changes at the end of the $20^{\text {th }}$ century, defined by the post-industrial era and resultant economic changes, changing welfare systems and social structures (Wacquant 1993, 368; Wacquant 2007, 67; Wacquant 2008, 169). Stigmatized areas, in this analysis, are perceived as 'dumping grounds' (Wacquant 1993, 368) and areas of containment (Wacquant 1993, 371) for victims of changing economic and ethno-racial structures.

While Wacquant and Slater primarily consider the role of politico-economic actors as the activators of stigma, Devereux et al. (2011a; 2011b) introduce the media as another actor whose powerful voice creates a form of territorial stigma. Using a discourse analysis of newspaper coverage rather than an ethnographic approach, their study of the stigmatized Moyross housing estate in Limerick, Ireland, shows the prevalence of certain themes and descriptors in the coverage of Moyross (Devereux et al. 2011a). Their study highlights the role of the media and mainstream press in presenting a negative image of an area (Devereux et al. 2011a). 
Wacquant, Slater, and Devereux et al. all consider the role of dominant forces and actors whose social, political or economic position allows them to create or promote territorial stigma, sometimes for economic ends. Even when these studies use ethnographic methods, the ultimate analysis focuses on power dynamics that permit the activation of stigma. Several studies have compared the role of powerful groups with powerless groups through considering internal and external perceptions of an area. These studies highlight that the dominant, negative view of an area is largely held by outsiders, and that insiders tend to hold a more positive view of the area in which they live (Jensen and Christensen 2012; Permentier et al. 2008; Rijnks and Strijker 2013). These studies, whilst acknowledging the dominant and powerful producers of stigma, give voice to those living in the area to highlight the perceived positive traits of the location or the mechanisms used to cope with presence in a denigrated locale.

While most literature that focuses on dominant actors who activate territorial stigma connect the phenomenon to "forms of inequality and stratified social relations" (Rhodes 2012, 699), James Rhodes' ethnographic study of territorial stigmatization among British National Party (BNP) members in the de-industrial city of Burnley shows that those involved in stigmatizing areas of the city do so based on perceived cultural or ethnic difference, thereby deflecting attention away from larger socioeconomic issues that create 'difference' (Rhodes 2012, 699). His study falls into the second category of work that considers the lived experience of reality from below or within a stigmatized location. The two focal approaches can be seen as differing in accordance to the voices that are dominant. In the first strand powerful voices that construct and activate stigma are the focus of the work, but the second strand foregrounds minoritarian voices that live and experience stigma daily. No study directly examines the differences in gender responses to stigma, however, and this is a gap that we attempt to address. 
While considering insider vs outsider perspectives, Jensen and Christensen also consider the role of actual and perceived cultural markers such as racism and difference as the foundations upon which territorial stigmatization are built. In their study of Aalborg East, Denmark, the authors contend, like Rhodes, that the visibility of race and ethnic difference is enough to trigger an imagined geography that invokes notions and fears of foreign 'ghettos', crime, danger and 'otherness' (Jensen and Christensen 2012, 83). Rhodes (2012) and Jensen and Christensen (2012) show that while territorial stigmatization may have a larger structural cause, at the micro-level individuals use cultural markers to build up their discourse of stigmatization and denigration.

Like Jensen and Christensen, Slater and Anderson (2011) highlight a sense of collective pride among residents of the stigmatized neighbourhood but, unlike the Danish study, Slater and Anderson's study from St Paul's, Bristol, shows that despite the pride, residents are acutely aware of the effects of living in a 'reputational ghetto', with respondents discussing judgement from friends, taxi drivers and other visitors (Slater and Anderson 2011, 10). The studies highlighted above that consider lived reality as the focus of study are primarily, effects-oriented. These studies add much to the debate but, by focusing on a single location (or locations), the data set is numerically and geographically limited. Though the 'powerful actors' focus picks up much of the state and economic power structures that can explain some structural, macroscale dynamics, neither they nor the lived-reality focus studies can capture at once an aspect of the national discourse that explains how people perceive and stigmatize certain places.

Our strategy to deal with this gap is to use the wealth of data available online that can engage in micro-level analysis at a wider scale. Rather than using ethnographic methods that can only capture the story of a particular place and its people, this study uses a large Twitter data set to 
allow individual voices to emerge while still giving a mappable, interpretable national picture of what people mean when they stigmatize place and what kinds of places they denigrate. Employing such an approach can move beyond the limits of one or two key locations presented in ethnographic studies (generally chosen as ideal or extreme types that represent locations assumed to be stigmatized), and can, instead, consider the national discourse of both insiders and outsiders at diverse locations. ${ }^{2}$ While it may not be able to reach the individual stories that ethnographic methods may elicit, using online data can give a bigger picture of where people stigmatize and what qualifies a place as being worthy of stigma. Indeed, our approach captures the fuller extent of the impact and prevalence of territorial stigma, noting that it is not limited to places of poverty and deprivation.

\section{Methodology}

This study began by a review of popular British literature, including the infamous Craptown books (Kieran and Jordison 2003; Kieran and Jordison 2004; Jordison and Kieran 2013) and important journalistic treatments (cf. Hatherley 2010). The Craptown books include an online component, which alerted us to the existence of other online forums that discuss and dissect locations using terms with obvious place-focused, derogatory intent, and widespread usage in the UK and Ireland. Within the popular discourse of denigration, we identified several key terms. The term 'craptowns' was popularized by books of the same name (Jordison and Kieran 2013; Kieran and Jordison 2003; Kieran and Jordison 2004). 'Armpit of England' is another popular term but is nation-specific, and places are often simply described adjectively as 'shit' or 'crap'. When examined against both Twitter data and online forums, it was clear that the term 'shithole' has common and widespread usage. ${ }^{3} 4$ By selecting and analysing this one key term it was possible to note trends and to engage in a level of qualitative analysis that would have been prohibitive with a larger data set that included more denigrating terms. 
To access a robust dataset that would permit capture of minoritarian voices that often drowned out by the majoritarian or dominant discourse, we elected to use the social media platform Twitter to gather the data to be used for further analysis. ${ }^{5}$ Twitter is a social media platform that allows users to microblog about their daily lives in 140 characters or less. There are 313 million monthly users worldwide (Twitter, 2016). The data for this study was collected by a Twitter Listener programme over a 155-day period between December 2015 and May 2016 to collect a sample of 2,337 tweets that included both a geotagged location and the term 'shithole'. The dates were selected so that our findings would be as current as possible. The 2,337 tweets all emanated from within the UK and Ireland and were directed mainly towards locations within these countries but also beyond, as discussed.

Each tweet was coded at three levels (Fig. 1). First, we sought to ascertain what, if anything, the user deemed to make a location a 'shithole'. Our analysis of the online forums, popular literature and responses to a failed online survey helped us see that that the term 'shithole' is employed to refer to: (1) a place defined by the type of people living there, (2) by a religious, racial or minority presence in an area, (3) by the area's socioeconomic factors, (4) by the area's physical attributes, and (5) by a lack of amenities in the area. Further codes such as those for crime, terrorism and rurality were generated per the content of tweets. We used an inductive open coding system, where all codes (including reaction codes) were generated according to data content. Where multiple codes fitted into one large umbrella category, they were grouped together under a master code.

[Fig. 1]

Second, we coded for the user's personal reaction to the 'shithole', such as defensive discourse, comparative discourse or synecdoche - the generalization of the whole based on only one part 
or aspect (Fig. 1). Finally, we developed relational geographies to explain the 'scales' at which the term 'shithole' was used or directed in the tweet. The geotagged location had to be checked for each tweet as the location corresponds not with the user's given own location but with the location through which he or she is passing at the time the tweet is published. Each tweet was checked and corrected for accuracy to ensure that the location of the user was the own location rather than a temporary location. This meant that we had to check the user's profile to ascertain their 'own' location from the details given, and to then categorise the location about which they were tweeting accordingly. If the tweeter was not posting about their 'own' location (i.e. where they state that they are from), the object of the tweet was categorised as 'other'. If the tweet was about the tweeter's home, school or place of employment, this was categorised as 'personal'. Tweets were thus categorized based on the geographic relation between the person and the object of the tweet (Table 1). The four main categories were: 1) "other" $(n=760)$, i.e. a tweet about a place that was not the home of the tweeter $\left.{ }^{6}, 2\right)$ "own" $(n=480)$, i.e. a reference to the tweeter's own area or region, 3) "particular facilities" $(n=462)$, like a sports stadium, which were so common as to deserve their own category, and 4) "personal" $(n=306)$, often a room or home or place of work. We include a miscellaneous category $(n=67)$ to capture tweets which did not fit into the main typology.

[Table 1]

After coding, tweets were deleted where the meaning of term 'shithole' could not be derived from the tweets or the larger tweet-based conversation, or where tweets were duplicated, resulting in a final sample size of 2,076 tweets. Tweets were then also coded for gender, determined by comparing the user's username, photographs, tweets and profile page biographical information or links to other personal websites or online profiles. Gender was only coded as 'male' or 'female' when these factors all pointed to the user being of that gender. Where gender was not obvious through examination of the user's Twitter profile, 
tweets were coded for gender as 'unknown'. ${ }^{7}$ The large data set $(n=2,076)$, combined with detailed qualitative analysis, allowed us to capture and analyse the voices of hundreds of women who would otherwise be hidden by the prevailing assertive male-dominated conversation that characterizes online interaction and disclosure (Herring, 1993). In this paper we do not quote directly from any of the tweets for reasons of confidentiality and traceability. We followed the ESRC's recommendation of consulting the British Psychological Society's four principles of ethical online research: "respect for autonomy and dignity of persons; scientific value; social responsibility; and maximising benefits and minimising harm" (2013, 2). As the data is found data that exists in the public domain, the best way in which we can protect the Twitter users whose tweets inform this study is by ensuring their confidentiality and inability to be traced. Even using a pseudonym with a quote would mean that the tweet's content could be used to trace the user. This is particularly troubling when the tweeter is from a small town or village where he or she may be the only member of the community using Twitter. Our ethical approval was granted on the understanding that we would not use any direct quotes in this paper so that Twitter users are protected from harm. We also refrain from naming any locations that were denigrated to prevent such places being further stigmatized. Readers are invited, however, to visit Twitter and search '\#shithole' to better understand the types of tweets we studied.

\section{Majoritarian voices, minoritarian voices}

Table 1 provides a thorough breakdown of the results of the coding process, showing how tweets are broken down into relational geographical categories and how each of these geographical levels is stigmatized according to gender. We see that cumulative 'other' geographies (i.e. other area, other city, other region, other nation, and international) were most frequently stigmatized and branded as 'shitholes' with $36.6 \%$ of all tweets directed at the 'other' 
geographical scale. Conversely, $23.1 \%$ of tweets were directed at the 'own' geographical scale (i.e. own area, microgeography of own city, own city, own region, and own nation). $22.3 \%$ of tweets labelled particular facilities (including sports facilities and stadia, and other facilities including leisure facilities) as 'shitholes'. Finally, $14.7 \%$ of tweets were directed at 'personal' geographies (those that refer to a Twitter user's immediate and intimate geographical surroundings, including individual rooms, homes, and places of work or education) ${ }^{8}$.

Across all geographical levels, it is clear that cities and sports facilities/stadia were denigrated most often. Analysis found that $29.4 \%$ of all tweets referred to the 'other city' level, followed by 'particular sports facilities' at $12.8 \%$ and 'own city' at $9.7 \%$ (see Table 1 ). These findings point to the fact that both at the cumulative category level (such as 'other' or 'own' geographies) and at the sub-category level (such as 'other city' or 'personal-home') that it is 'other' geographies that are most stigmatized and, as such, we can see that the majority of stigmatizing is directed at places rather from within places. That is, the stigmatizating occurs at a distance and these 'other geographies' tweets generally appear based on visits or external perception of place rather than an internal or lived experience. This finding is in line with other studies such as that of Devereux et al. (2011b) which highlight the primacy of external stigmatizing constructions of place often as part of a larger political economic campaign.

While not all users specify a particular attribute that they deem paramount in a place being considered a 'shithole' and worthy of denigration, of those that do, demographic characteristics, including presence of a religious group, accent, migration, racial group, racist group and type of people ${ }^{9}$ and politico-economic traits are common at the 'other geographies' scale (Fig. 2). Evident, too, is that the 'other city' scale is often tied to a sporting rivalry, with $46.7 \%$ of tweets at the 'other city' level linking a city and a sports team/stadium, suggesting that Twitter 
users engage in synecdoche: they denigrate an entire town or city because of the presence of a particular sports team. This furthers the notion of denigration being used as a method of othering, stratification, and self-identification based on definition of an 'other'.

[Fig. 2]

Although synecdoche is used as a reaction to presence in or proximity to a perceived shithole, it is not the most common reaction used at the 'other geographies' scale. Most commonly employed is comparative discourse (Fig. 3), which serves to further separate the Twitter users from the location about which they speak. By comparing the 'shithole' or denigrated place to another area, the user asserts distance from the denigrated place, contributing to a popular hierarchy and stratification of places. By using geotagged locations it is also possible to note the 'hot-spots' of denigration at the 'other city' scale and, as might be expected, it is major urban areas that are stigmatized by outsiders but, as will be discussed later, the stigma is not limited to these urban areas.

The data shows clearly that it is an 'other' place that is most regularly stigmatized $(36.6 \%)$. Most often, these dominant voices are men, and these male voices tend to stigmatize at the urban scale, and respond to denigration with comparative discourse thereby putting distance between the self and the denigrated. These dominant or majoritarian voices reinforce the Bourdieusian interpretation of society put forth by Wacquant in his conceptualization of territorial stigmatization (Bourdieu 1991; Wacquant 2008; Slater 2016). In such a vision, symbolic power is enabled by a dominant group to impose a vision of society and to shape and stratify society (Wacquant 2014: 1699; Slater 2016). The majoritarian voices we hear in the Twitter data inform, are informed by, and (re)produce the dominant groups, creating visions of society. Crucially, as we see from the data, most of these voices are talking about 'other' places, places that they are visiting or on which they paint stigmatizing imagery from a 
distance. Powerful majorities claim the debate and replicate the same tropes of race, physical dereliction, and class to create a discourse of denigration for political or economic ends (see Gourlay 2007; Gray and Mooney 2011; Hancock and Mooney 2011; Hastings and Dean 2003; Kallin and Slater 2014; Shaw and Porter 2009; Porter, 2013; Slater, 2017). But dominant voices, by writing from the outside or from-above, from positions of power and externality, do not capture the lived reality and the true views emerging from within a stigmatized location. They do not represent the silenced voices who offer a different perspective on what constitutes a denigrated location.

\section{Digging beneath the dominant noise}

Although most tweets talk about 'other' geographies, an important set of findings emerge from the non-dominant or minoritarian voices. Many of the 'own geography' tweets come from those who want to remove themselves from the geographies in which they find themselves, and who use the language of territorial stigma to do this. The 'own' geographies tweets relate in our relational geographical structure to own area, own city, own region and own nation. On the other hand, 'personal' tweets relate to a more intimate geography of home, education or work place. These minoritarian voices that are most apparent in the 'own' and 'personal' geographies which account for $23.1 \%$ and $11.4 \%$ of tweets respectively. Even combined they do not equal the $36.6 \%$ of tweets that are directed at 'other geographies', but it is here that we find alternative reasons given as to what constitutes a denigrated place and what discursive reactions users take.

[Fig. 4]

At the 'own geographies' scale, demographic characteristics and politico-economic change are, as with the 'other geographies' scale, seen to be characteristics that make a place worthy of 
denigration. However, we also see that the physical surroundings and amenities become important at the 'own' scale (Fig. 4). Users pay attention to and stigmatize based on the appearance and physical degradation of their area, and they are also acutely aware of what is missing. They define a denigrated place based on what is lacking, on the lack of amenities and connections, and the perceived level of 'boredom' elicited by the location. At the 'personal geographies' scale, however, specific attributes are rarely given and we are simply left with the discursive reaction of a desire to escape, which echoes as a cry for help. For, at both 'own' and 'personal' scales, 'desire to leave' is used overwhelmingly as the reaction to presence in a denigrated place (see Figs. 5 and 6). As discussed in the following section, it is women who most often employ 'desire to leave' as a response.

[Fig. 5]

[Fig. 6]

\section{Gendered voices}

Research on online communication and gender tells us that there is a gender divide in terms of what males and females communicate online and the language they use. Online communication often falls "in line with the public man/private woman dichotomy that has been previously identified in gender research" (Herring et al. 2007, 17). Further, women are more likely to write with "their own lives as their subject" whereas men tend to write about other than themselves (Courtney Walton and Rice 2013, 1467). In terms of the language and register used online, where men use authoritative language, assertion, sarcasm, and challenging language (Herring 1993), women are more defensive and supportive, using apologies, justifications, and discussion based on personal values and experiences (Herring 1993).

From this, we might hypothesize that the discourse of denigration - a discourse of assertion, authority and othering that fits Herring's model of language and register (Herring 1993) - 
would be primarily male-dominated. Our study largely confirms this hypothesis. Although Sloan et al.'s study of a month of worldwide tweets in July 2012 tells us that Twitter users are roughly split between genders with $45 \%$ of Twitter users having a male name, $47 \%$ having a female name and $8 \%$ having a unisex name (2013), in our sample of 2,076 tweets, $70.3 \%$ of tweets were from males, $28.2 \%$ were from females with the remaining $1.4 \%$ from those whose gender was not ascertainable or who had a male-female shared account. This suggests that the shithole discourse, in which the majority of tweets are directed towards the 'other' scale in the UK and Ireland is, generally, male-dominated. ${ }^{10}$ This is particularly revealing as, while the discourse of denigration appears to be an authoritative, male-dominated discourse, women are equal — if not more frequent — users of the term 'shit' and its variants (Singleton 2000; Fälthammar Schippers 2013; Zuchowski 2015). This highlights that despite even usage of the term 'shit' and its variants in multiples discourses, in the discourse of denigration it is males who dominate the discussion.

While men are the primary stigmatizers of place, they are only the prime stigmatizers only at the 'other' scale ( $83.3 \%$ male, $14.6 \%$ female) and 'particular facilities' scale ( $87.7 \%$ male, $11.7 \%$ female, $0.4 \%$ unknown, $0.2 \%$ shared male and female account), the latter a reflection of the centrality of football to the shithole discourse in the UK. At the 'own' scale, the gender divide is more evenly split ( $54.0 \%$ male, $44.4 \%$ female), and it is females who overwhelmingly stigmatize 'personal' locations (35.6\% male, 63.4\% female) (see Fig. 2). Males engaged most in the discourse of denigration and were most frequently active in discussions of other locations - either specific 'other' geographic locations such as towns, areas within towns, regions or nations, or 'other' facilities to which they have no personal, lived or intimate connection. Females were active in the discussion of 'own' geographies almost as much as 
men, but they were most vocal and active at the personal geographic scale stigmatizing and denigrating their own personal geographies.

Further difference in gender can be seen in users' reactions to proximity to or presence in a perceived shithole. By 'reaction', we refer to the discursive response exhibited including affectionate or defensive discourse, comparative discourse and, commonly, a statement of a desire to leave. Only 4 users ( 3 males, 1 female) use direct distancing as a discursive response (for example, expressing sentiments of relief about not being from a particular place) but all discursive responses apart from affectionate/defensive discourse can be read as a means of indirect distancing. By noting a place is a 'shithole' and passing judgement, already the user is seeking to draw a division between self and place.

The difference between genders can be seen particularly in these reactions. Male tweeters frequently used comparative discourse to react to presence in a perceived shithole, which served as a means of separating and othering, echoing back to Courtney Walton and Rice's findings that men tend to write about things other than themselves (2013: 1467). By engaging in a reaction to a perceived shithole that is comparative, men increased this tendency to 'other' and to separate themselves, drawing a distinction and highlighting that what they are discussing is public rather than private. Women, however, offered a more personal response and, at all but the 'particular facilities' scale, ${ }^{11}$ women react to proximity to or presence in a perceived shithole by stating a desire to leave (compare figures 3, 6, 7 and 8). While this, too, suggests a separation, it suggests a desire to separate, a desire that stems from an existing and enduring connection to a place. It implies a wish to sever ties with a place that they have experienced intimately. Female voices in the data are less assertive and challenging and more emotionallycharged, suggesting a desire to remove an element of fixity to a place, at least discursively. 
Their reaction of desiring to escape can be read as a desire to convert a lived and experienced place ascribed with emotion into a distant space from which they can remove their emotional and experiential ties.

While our findings affirm current literature in online psychology and linguistics that notes that males are engaged in assertive discourse about things 'other' or distant from themselves and their own personal space, we can add a spatial dimension and highlight that there are geographical scales inherent in the discourse of denigration. More importantly, while male voices may dominant, female voices play a critical role in shithole discourse. Women's engagement in the discourse of denigration occurs at the 'personal' scale and, to a lesser extent, at the 'own' scale both of which are built on lived experience in geographies of quotidian life.

\section{Interpreting minoritarian voices}

The territorial stigmatization literature largely explains the majoritarian voices captured in our study. Studies by Wacquant (1993; 2007; 2008) and Slater (Slater and Anderson, 2011; Kallin and Slater 2014; Slater 2017) highlight the racial and class motivations for stigmatization by powerful actors of disadvantaged peoples and places. But, the main body of territorial stigmatization literature rarely extends to 'ordinary' places, to consider the towns, cities and rural villages of the UK and Ireland and the attendant ability for all of these places to be perceived as a 'shithole'. Nor can this literature entirely explain the gendered differences that our study located.

The concept of territoriality, a type of "super place attachment" (Kintrea et al. 2008) may help to understand the connection young males have to place (ibid; Pickering et al. 2011). The data shows clearly that it is young males who practise this form of territorial behaviour most, using 
overt displays or actions to defend their territory against 'others'. This overt display of behaviour directed towards an 'other' fits with research on online communication gender patterns, which tell us that where women tend to respond in a defensive manner about their own lives or situations, men tend to respond with assertive, challenging language that is directed towards an 'other' (Courtney Walton and Rice 2013; Herring 1993; Herring et al. 2007). Territoriality, then, can provide an understanding of how males may respond to 'other' geographies that they perceive as threatening in some way to their own, for example in terms of sporting rivalry. But, territoriality cannot explain why women respond with boundarymaking discourse. Similarly, denigrating a location with others in that location may amount to a bonding mechanism that is used to foster identity and commonality among young people dwelling in a perceived 'shithole'. While this would explain the situation for women, it does not explain why men direct their shithole discourse elsewhere.

Disaffiliation, a lack of elective belonging (Watt 2009, 2875; Pinkster 2013, 811) can answer questions about class and boundary-making. The literature on disaffiliation acknowledges that "place... has become part of conspicuous consumption and a tool to distinguish and distance oneself from 'others"' (Pinkster 2013, 810) and highlights the practices of middle-class residents to separate and segregate (Atkinson 2006, 819) themselves from other social classes and places (Watt 2009, 2875). By creating enclaves and clusters away from other social classes, the middle-class seeks to distance themselves from fellow residents of a location and characteristics of the location itself. This explanation is useful when considering gentrified areas or areas of white or middle-class populations, but it cannot explain fully the desire to create a boundary between self and place as our study shows. 
As can be seen, there are several ways of approaching the data findings. We argue that one useful way to interpret the minoritarian views highlighted above, especially those of women, is through the lens of abjection. Here we move beyond traditional psychoanalytic (Kristeva 1982) and social conceptualizations of abjection and the abject (Tyler 2013) and consider, instead, how abjection can be applied at a spatial level. We extend the definition to understand how residents use territorial stigma to separate self from place, thus contributing to a geography of abject places.

Abjection can be applied spatially, building on Judith Butler's "'unlivable' and 'uninhabitable' zones of social life which are nevertheless densely populated by those who do not enjoy the status of the subject" (Butler 1993, 3). Adéle Nel's work on cinematic representation of abject Johannesburg progresses the idea of the city as abject. She explains that "the abject is also concerned with space, and the term 'space of abjection' is sometimes used to refer to a space inhabited by abjected things or beings" (Nel 2013, 139). Both Butler and Nel imply that it is the presence of an abject population and the state's response to this population (such as the use of enforced segregation, barbed wire fences, security cameras etc.), which constitute an abject geography. However, the discourse of denigration studied in this project tells us that it is not always the demographics of an area that make it worthy of denigration and condemnation. Especially if we listen to minoritarian voices at the 'own geographies' scale, we hear that it is often appearances and lack of amenities that contribute to making a 'shithole'. We see that it is not always the state's active response to the presence of a demographic group in a particular area but the presence of, for example, litter or poor housing that might lead to residents maligning an area. This theorisation of spatial abjection requires further investigation but we find it a useful tool in preliminarily understanding the data. 
It is the minoritarian voices who express a wish to leave an area who provide a compelling account of separating the self from place. They highlight a desire to restructure the relationship between self and place even if a physical separation is not possible. These Twitter users attempt to discursively distance themselves in order to create a division between self and place. Where dominant voices may engage in comparative discourse that allows a direct reinforcement of difference, non-dominant voices who use 'desire to leave' as a discursive response express a desire to be separate and begin to highlight difference between self and place. While they may be bodily present in a denigrated location, stating a desire to leave suggests that the user is not themselves worthy of denigration and wishes to be seen as different, other, and separate from such a place. This 'desire to leave' constitutes a form of 'othering' - the othering process is inverted and reflected back on the self, making the self different and separate to the location. As users seek to create distance between self and place and, in effect spatialize place, they attempt to remove from it the emotions and personal attributes that connect it to self and, instead, to imbue a location with tarnishing discourse and attributes. We see that such users, while trying to free themselves from the spatial taint that may transfer and stain the self, actually further add to the press of stigma that lies heavy on the location. ${ }^{12}$

Through this process of othering, they expel from their sense of self the label and stigma of place. In the process of expulsion, they create a notion of abject places that are removed from self-identity. This process of expulsion results in a form of boundary-making between self and space, which at once further contributes to territorial stigma and is a form of abjection in a Kristevan sense. It is entirely at odds with the sense of 'pride' that Slater and Anderson (2011) and Jensen and Christensen (2012) note in their ethnographic studies. In our study, we find that this desire to separate and to expel place from the self is commonly found amongst those directing the discourse at their own places. 
However, the notion of a particular geography of abjection is problematic. When we analyse the data, we can find no pattern to denigration and abjection: individuals cry for help and want to leave virtually everywhere and every type of place. They want to leave dirty, ill-equipped homes, villages that are boring, towns that lack amenities, and cities that are dirty and full of 'others'. Everywhere in Britain and Ireland becomes part or has the potential to become part of the geography of abjection, returning us back to cultural understandings of stigmatization (Jensen and Christensen 2012; Rhodes 2012) to understand those, who, when confronted with difference or lack, seek to create boundaries and borders. When we consider stigmatization of place, most voices engaged from afar as a means to distance and denigrate for political, social or economic means. But even for those who aim the discourse at their own places, everywhere has the potential to be denigrated by its residents. Any markers of difference feed into a tendency to denigrate, stigmatize, and to attempt to expel place from self-identity. In this way, the process of territorial stigmatization seems to be a coping mechanism; it is as much about coping with life in a stigmatized place, as it is about using territorial stigma to cope.

\section{Conclusion}

While there is clear evidence that the a male-dominated majority speaks in ways that match neatly with the state's use of stigmatization based on demographic difference and politicoeconomic difference, and distancing of 'other' geographies, a significant minority of voices gave us a different picture. Where the dominant, majoritarian voices are men who 'other' places to which they have no intimate connection, it is women who are vocal at the 'own' and 'personal' geographic scales, suggesting that women stigmatize geographies of quotidian experience far more than 'other' geographies. While their voices in Twitter data are often drowned out by the dominant male voices, a robust data sample allowed us to analyse hundreds 
of women engaging in stigmatization. Similarly, we were able to hear other minoritarian voices in the dataset. These voices underscored the diverse criteria used by individuals to establish whether or not a place is worthy of stigmatization and we see that political, social, demographic and cultural markers discussed in the literature are nt always present in the minoritarian denigration, which highlight markers of difference of any sort, including those defined by a lack or absence, and physical appearance. Our paper highlights the need to consider national discourses of denigration which the literature has not seen before in order to examine the everyday discourse of denigration and the imagined geography of a nation.

These findings push us to have a broader view of territorial stigmatization and how and why it is produced. We see that anywhere is a potential target for stigmatization, and that while the voices of outsiders decrying cultural difference might be loudest, there are valuable lessons to be learned from the quieter voices living in quotidian geographies defined by lack, boredom and physical degradation, from which they desire to escape. One question which remains is how these two discourses interact, and to what extent what are essentially cries for help unwittingly reproduce the negative depiction of place.

Our inability to find major substantial geographic difference in the use of shithole in the UK also demands a deeper dive into the culture of denigration in the UK and Ireland. There is some evidence that the tendency to denigrate place appears stronger in England than in Northern Ireland, Scotland, Wales and Ireland, but far more research is necessary. Is this a result of analysing one specific term that may have more widespread usage in England or does it hint at a cultural tendency to view and stigmatize place? Certainly, we know that there are different ways in which states use and manipulate denigration (Wacquant 2008) but does this transfer from a macro- to a micro-level? More research is be required to address a link between the 
construction of negative place image and national or regional cultures, but this study has highlighted that the tendency to stigmatize is widespread, not limited to dense urban areas, and not limited solely to demographic or politico-economic difference.

While we think that methodologically we have made an important contribution, much more could be done with a larger dataset, different coding mechanisms, or other sort of similar nonelicited data. We are currently working with computer scientists to use this coding structure to build machine learning mechanisms that will enable a big data approach that may provide some better evidence as to geographical difference. There are many ways in which this work could be combined with critical ethnography, visual methods, and discourse analysis, especially with regards to the culture of denigration and territorial stigma. Further studies could usefully compare the temporal distribution of tweets with wider events in politics and society to ascertain if there is a correlation between the discourse of denigration and current affairs. There is also a clear need to go beyond the boundaries of social science, in particular into areas of social psychology which have methodological tools designed to better understand how people think and why they think what they think or say what they say. Territorial stigma in the UK and Ireland is a widespread cultural phenomenon, not just a tool of the powerful, and there is much more to learn about why this language is so widespread if we are going to combat the negative impacts of the constant stream of invective aimed at the everyday places and spaces of the UK and Ireland.

\section{References}

Armentor-Cota J 2011 Multiple perspectives on the influence of gender in online interactions Sociology Compass 5 23-36 
Atkinson R 2006 Padding the bunker: Strategies of middle-class disaffiliation and colonisation in the city Urban Studies 43 819-832

Bataille G 1993 [1934] Abjection and miserable forms in Lotringer S and Lotringer S eds More \& Less 2 Trans Y Shafir Semiotext(e), Los Angeles, CA 6-13

Bourdieu P 1991 Language and symbolic power Edited by John B Thompson Harvard University Press, Cambridge, MA

British Psychological Society 2013 Ethics Guidelines for Internet-mediated Research (http://www.bps.org.uk/system/files/Public\%20files/inf206-guidelines-for-internet-mediatedresearch.pdf) Accessed 23 December 2016

Butler J P 1993 Bodies that matter: On the discursive limits of 'sex' Routledge, New York Courtney Walton S and Rice R E 2013 Mediated disclosure on Twitter: The roles of gender and identity in boundary impermeability, valence, disclosure, and stage Computers in Human Behavior 29 1465-1474

Damer S 1974 Wine Alley: the sociology of a dreadful enclosure The Sociological Review 22 $221-248$

Damer S 1989 From Moorepark to 'Wine Alley' Edinburgh University Press, Edinburgh Davie M R 1932 Problems of city life: a study in urban sociology Wiley, New York Devereux E, Haynes A and Power M J 2011a At the edge: Media constructions of a stigmatised Irish housing estate Journal of Housing and the Built Environment 26 123-142 Devereux E, Haynes A and Power M J 2011b Tarring everyone with the same shorthand? Journalists, stigmatization and social exclusion Journalism 13 500-517 Fairclough N 1995 Critical discourse analysis: The critical study of language Longman, London

Fälthammar Schippers A 2013 "Bad Language in Reality -A study of swear words, expletives and gender in reality television." Göteborgs Universitet. 
Firey W 1945 Sentiment and symbolism as ecological variables American Sociological Review 10 140-148

Gill O 1977 Luke Street Macmillan Press, London

Gourlay G 2007 "It's got a bad name and it sticks...” Approaching stigma as a distinct focus of neighbourhood regeneration initiatives'.

Gray N and Mooney G 2011 Glasgow's new urban frontier: "Civilising" the population of "Glasgow east" City 15 4-24

Hancock L and Mooney G 2011 "Saints and scroungers": Constructing the poverty and crime myth Criminal Justice Matters 83 26-27

Hastings A 2004 Stigma and social housing estates: Beyond pathological explanations Journal of Housing and the Built Environment 19 233-254

Hastings A and Dean J 2003 Challenging images: Tackling stigma through estate regeneration Policy \& Politics 31 171-184

Hatherley O 2011 A guide to the new ruins of Great Britain Verso Books, London Herring S C 1993 Gender and democracy in computer-mediated communication The Electronic Journal of Communication 3

Herring S C, Scheidt L A, Kouper I and Wright E 2007 A longitudinal content analysis of weblogs: 2003-2004, in Tremayne M ed Citizenship and the future of media Routledge, London 3-20

Holt A and Wilkins C 2014 “In some eyes it's still Oooh, Gloucester, yeah Fred West”: Spatial stigma and the impact of a high-profile crime on community identity Journal of Community \& Applied Social Psychology 25 82-94

Hum N J, Chamberlin P E, Hambright B L, Portwood A C, Schat A C and Bevan J L 2011 A picture is worth a thousand words: a content analysis of Facebook profile photographs Computers in Human Behavior 27 1828-33 
Jensen S Q and Christensen A-D 2012 Territorial stigmatization and local belonging City $1674-92$

Jordison S and Kieran D eds 2013 Crap towns returns: Back by unpopular demand. Quercus Publishing, United Kingdom

Kallin H and Slater T 2014 Activating territorial stigma: gentrifying marginality on Edinburgh's periphery Environment and Planning A 46 1351-1368

Keene D E and Padilla M B 2010 Race, class and the stigma of place: Moving to "opportunity" in Eastern Iowa Health \& Place 16 1216-1223

Kieran D and Jordison S eds 2003 The Idler book of Crap Towns: The 50 worst places to live in the UK Boxtree, United Kingdom

Kieran D and Jordison S eds 2004 The Idler book of Crap Towns II: The nation decides: The new top 50 worst places to live in the UK Boxtree, United Kingdom Kintrea K, Bannister J, Pickering J, Reid M and Suzuki N 2008 Young people and territoriality

in British cities Joseph Rowntree Foundation, York

Kornberg D 2016 The structural origins of territorial stigma: Water and racial politics in metropolitan Detroit, 1950s-2010s International Journal of Urban and Regional Research 40 $263-283$

Kristeva J 1982 Powers of horror: An essay on abjection Trans. L S Roudiez Columbia University Press, New York

Link B G and Phelan J C 2001 Conceptualizing stigma Annual Review of Sociology $27363-385$

Morris A 2013 Public housing in Australia: A case of advanced urban marginality? The Economic and Labour Relations Review 24 80-96

Nel A 2012 The repugnant appeal of the abject: Cityscape and cinematic corporality in 
District 9 Critical Arts 26 547-569

Nel A 2013 Borders and abjection in Triomf in Viljoen H ed Crossing borders, dissolving boundaries Editions Rodopi B V, Amsterdam 135-154

Office for National Statistics 2016 Internal migration, England and Wales: Year ending

June

(https://www.ons.gov.uk/peoplepopulationandcommunity/populationandmigration/migration withintheuk/bulletins/internalmigrationbylocalauthoritiesinenglandandwales/yearendingjune2

015) Accessed 20 October 2016

Oxford English Dictionary 2016 Shithole

(https://wam.leeds.ac.uk/wamvalidate?url=http\%3A\%2F\%2F0-

www.oed.com.wam.leeds.ac.uk\%3A80\%2Fview $\% 2$ FEntry $\% 2 \mathrm{~F} 276883 \% 3$ FredirectedFrom $\%$

3Dshithole\#eid) Accessed 7 October 2016

Pearce J (2012) The "blemish of place": Stigma, geography and health inequalities. A

commentary on Tabuchi, Fukuhara \& Iso Social Science \& Medicine 75 1921-1924

Permentier M, van Ham M and Bolt G 2008 Same neighbourhood ... different views? A confrontation of internal and external neighbourhood reputations Housing Studies 23 833-855

Pickering J, Kintrea K and Bannister J 2011 Invisible walls and visible youth: Territoriality among young people in British cities Urban Studies 49 945-60

Pinkster F M 2014 “I just live here”: Everyday practices of disaffiliation of middle-class households in disadvantaged neighbourhoods Urban Studies 51 810-26

Porter L 2013 Whose urban renaissance? in Porter L and Shaw K eds Whose urbarenaissance? An international comparison of urban regeneration strategies Routledge Abingdon 241-52

Rhodes J 2012 Stigmatization, space, and boundaries in de-industrial Burnley Ethnic and Racial Studies 35 684-703 
Rijnks R H and Strijker D 2013 Spatial effects on the image and identity of a rural area Journal of Environmental Psychology 36 103-11

Rozin P and Fallon A E 1987 A perspective on disgust Psychological Review 94 23-41

Schultz Larsen T 2014 Copenhagen's west end a "paradise lost": The political production of territorial stigmatization in Denmark Environment and Planning A 46 1386-1402

Shaw K and Porter L 2009 Introduction in Porter L and Shaw K eds Whose urban renaissance? An international comparison of urban regeneration strategies Routledge, London 1-7

Sibley D 1995 Geographies of exclusion Routledge, London

Singleton D 2000 Language and the Lexicon: an introduction Routledge, London

Slater T 2017, forthcoming Territorial Stigmatization: Symbolic Defamation and the Contemporary Metropolis in Hannigan $\mathbf{J}$ and Richards G eds The Handbook of New Urban Studies Sage Publications, London

Slater T 2016 Loïc Wacquant in Latham A and Koch R eds Key thinkers on cities Sage Publications, London

Slater T and Anderson N 2011 The reputational ghetto: territorial stigmatisation in St Paul's, Bristol Transactions of the Institute of British Geographers 37 530-46

\section{Sloan L, Morgan J, Housley W, Williams M, Edwards A, Burnap P and Rana O}

2013 Knowing the Tweeters: Deriving sociologically relevant demographics from Twitter Sociological Research Online 18

Tucker J 1966 Honourable Estates Gollancz

Twitter 2016 What's happening (https://about.twitter.com/company) Accessed 7 October 2016

Tyler I 2013 Revolting subjects social abjection and resistance in neoliberal Britain Zed Books, London 
Wacquant L 1993 Urban Outcasts: Stigma and Division in the Black American Ghetto and the French Urban Periphery International Journal of Urban and Regional Research 17 $366-83$

Wacquant L 1996 The rise of advanced marginality: Notes on its nature and implications Acta Sociologica 39 121-139

Wacquant L 2007 Territorial Stigmatization in the age of advanced marginality Thesis Eleven 91 66-77.

Wacquant L 2008 Urban Outcasts: A Comparative Sociology of Advanced Marginality Polity Press, Cambridge

Wacquant L 2014 Marginality, ethnicity and penality in the neo-liberal city: An analytic Cartography Ethnic and Racial Studies 37 1687-1711

Wacquant L, Slater T and Pereira V B 2014 'Territorial stigmatization in action, Environment and Planning A 46 1270-80

Watt P 2009 Living in an oasis: Middle-class disaffiliation and selective belonging in an English suburb Environment and Planning A 41 2874-2892

Zhao S, Grasmuck S and Martin J 2008 Identity construction on Facebook: digital empowerment in anchored relationships Computers in Human Behavior 24 1816-36

Zuchowski D "Women give more shit." Strong Language. March 01, 2015. Accessed September 08, 2017. https://stronglang.wordpress.com/2015/03/01/women-give-more-shit/.

\section{Notes}

\footnotetext{
${ }^{1}$ By 'minoritarian' we refer to those who do not constitute the statistical majority in the datatset. We do not imply that this group is marginalized in any way.

${ }^{2}$ Permentier et al's study of Kanaleineiland, Utrecht considers insiders and outsider but only at one specific location. Their findings also involve discussion of particular facilities, physical appearances, and demographics (2008).

${ }^{3}$ Regional variants of the term 'shithole' exist ('shitehole' and 'shitehouse', for example, are common in Scotland), but shithole was the most common and widespread, rendering it the most suitable term for a widespread analysis of the discourse of denigration in the UK and Ireland. The term 'shithole' has four meanings ranging from the anatomical to the geographical (Oxford English Dictionary, 2016). First used in 1629 , 'shithole' referred to the anus or rectum. Some three centuries later in 1930, the term was first used to
} 
refer to "a wretched place" (OED, 2016). By 1947, a third use had emerged that referred to a toilet and by 1974, the term was used to describe a person, as an alternative to the term 'asshole' (OED, 2016).

${ }^{4}$ Although there is no single study that determines the gendered usage of the term 'shithole' and other scatological terms, Fälthammar Schippers has studied the use of expletives in the reality television shows Jersey Shore and Geordie Shore. Her study shows that 'shit' as a noun is used by more men than women, but that 'shit/-ty' as an adjective is an almost even split. 'Shit' as an interjection, however is used vastly by more women than men $(2013,22)$. Singleton also makes the claim that the gap between male and female usage of the term 'shit' has narrowed with women far more ready to use the term than they would have been in the past $(2000,118)$. Further, Zuchowski in an informal online study of the British National Corpus reveals that rather than merely narrow the gap, women are more likely to use the term 'shit' and its variants (Zuchowski).

${ }^{5}$ A pilot study of a survey distributed on online forums proved problematic from a methodological perspective. It became clear that nonreactive, found data was better for the purposes of understanding meaning, at least outside of the context of formal social psychological research. This pilot study, however, proved useful when combined with the analysis of the popular literature and the online forums as part of an iterative process for developing a robust coding mechanism.

${ }^{6}$ By 'home' we refer to a house or place of residence rather than a region or neighbourhood.

${ }^{7}$ The online world is different to the offline world where people rely on face-to-face interaction and visible characteristics and markers to determine gender, race, age etc. (Zhao et al. 2008, 1818). The online world can be divided into anonymous and nonymous worlds (Zhao et al. 2008; Hum et al 2011). The former, including chat rooms and role-player games, is defined by the lack of anchored relationships (relationships that connect the offline to the online world) and in these interactions gender swapping and gender fluidity are noted with $28 \%$ of users in a study presenting themselves as a different gender (Samp et al. 2003 in Armentor-Cota, 2011). However, in nonymized worlds such as Facebook and Twitter, online presence is linked to offline relationships through communication and contact with friends, colleagues, family, and links to work, school and other anchoring forces. While Zhao et al. note that the construction of identities in nonymized online settings is understudied, it is apparent that users in nonymized online environments present more closely to their offline personae than do users in anonymized online environments. In this paper, we follow work by others studying nonymized disclosure (see, for example, Courtney Walton and Rice 2013) and assign a gender classification to Twitter users according to visible markers presented on their profiles and embedded links. Where no gender information is provided or where visible markers are not available, we assigned a code of 'unknown' reflecting the lack of data available. We acknowledge that it is not possible to entirely eliminate the possibility of 'gender fraud' and that some readers may perceive all literature that follows the methods we have used as reproducing the problematic but we feel that, as with other literature in the field of online disclosure, our findings are valid and can present insight into the role of gender in stigmatizing place.

${ }^{8}$ The remaining $3.2 \%$ of tweets refer to miscellaneous categories such as non-places (life, situations, etc.), nonspecific locations (e.g. 'lefty shitholes'), specific streets, or the entire world.

${ }^{9}$ 'Type of people' generally, but never explicitly, refers to perceived class dynamics and difference.

${ }^{10}$ The gender of users in this study was determined by comparing the user's username, photographs, tweets and biographical information. Gender was only coded as 'male' or 'female' when these factors all pointed to the user being of that particular gender. Otherwise, keeping in mind the notions of gender fluidity used in online interactions as noted by Janet Armentor-Cota (2011), tweets were coded as 'unknown'.

${ }^{11}$ At the 'particular facilities' scale, women use affectionate/defensive discursive responses more than they utilise a desire to leave as a response.

${ }^{12}$ While it is beyond the aims of this paper to determine whether users who 'desired to leave' actually attempted to exit their personal or own geographical area, the locations were compared to the Office for National Statistics' internal migration data to establish whether there was a correlation between the towns and cities that those engaging in the discourse of denigration seek to leave and a negative net migration rate for the local authorities in which those areas are found (Office for National Statistics, 2016). No such correlation was evident, suggesting that the 'desire to leave' serves only as discursive response to being in a self-reported denigrated area. 


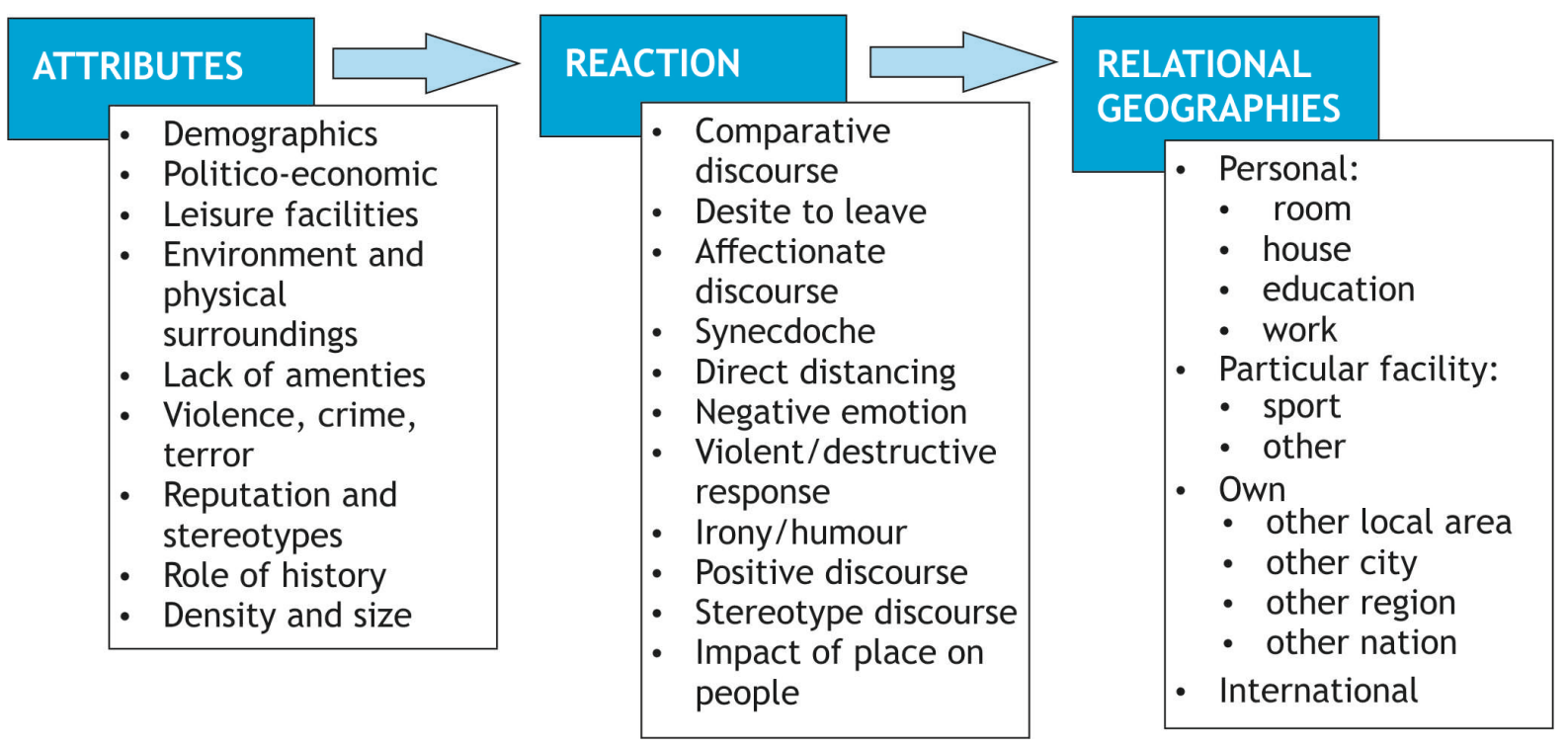

Figure 1: coding process showing the multiple levels at which each code was coded.

\begin{tabular}{|c|c|c|c|c|c|c|c|c|c|c|}
\hline \multirow{2}{*}{$\begin{array}{l}\text { Relational geographical scale } \\
\text { OTHER }\end{array}$} & \multirow{2}{*}{$\begin{array}{l}\begin{array}{l}\text { Number of } \\
\text { tweets }(T)\end{array} \\
760\end{array}$} & \multirow{2}{*}{$\begin{array}{l}\text { Nof total sample } \\
\text { (n=2,076) }\end{array}$} & \multicolumn{2}{|c|}{$\begin{array}{c}\text { Male } \\
\text { (number and } \\
\text { percentage of T) }\end{array}$} & \multicolumn{2}{|c|}{$\begin{array}{c}\text { Female } \\
\text { (number and } \\
\text { percentage of } \mathrm{T} \text { ) }\end{array}$} & \multicolumn{2}{|c|}{$\begin{array}{l}\text { Unknown gender } \\
\text { (number and } \\
\text { percentage of } \mathrm{T} \text { ) }\end{array}$} & \multicolumn{2}{|c|}{$\begin{array}{c}\text { Shared M\&F account } \\
\text { (number and } \\
\text { percentage of } T \text { ) }\end{array}$} \\
\hline & & & 633 & $83.3 \%$ & 111 & $14.6 \%$ & 15 & $2.0 \%$ & 1 & $0.1 \%$ \\
\hline Other area & 20 & $1.0 \%$ & 16 & $80.0 \%$ & 3 & $15.0 \%$ & & & 1 & $5.0 \%$ \\
\hline Other city & 610 & $29.4 \%$ & 507 & $83.1 \%$ & 93 & $15.2 \%$ & 10 & $1.6 \%$ & & \\
\hline Other region & 27 & $1.3 \%$ & 25 & $92.6 \%$ & 2 & $7.4 \mathrm{~s}$ & & & & \\
\hline Other nation & 46 & $2.2 \%$ & 37 & $80.4 \%$ & 6 & $13.0 \%$ & 3 & $6.5 \%$ & & \\
\hline International & 57 & $2.7 \%$ & 48 & $84.2 \%$ & 7 & $12.3 \%$ & 2 & $3.5 \%$ & & \\
\hline OWN & 480 & $23.1 \%$ & 259 & $54.0 \%$ & 213 & $44,4 \%$ & 8 & $1.7 \%$ & & \\
\hline Own area & 146 & $7.0 \%$ & 59 & $40,4 \%$ & 87 & $59,6 \%$ & & & & \\
\hline Microgeography of own city & 59 & $2.8 \%$ & 42 & $71.2 \%$ & 13 & $22.0 \%$ & 4 & $6.8 \%$ & & \\
\hline Own city & 202 & $9.7 \%$ & 105 & $52.0 \%$ & 95 & 47.06 & 2 & $1.0 \%$ & & \\
\hline Own region & 17 & $0.8 \%$ & 11 & $64.7 \%$ & 6 & $35.3 \%$ & & & & \\
\hline Own nation & 56 & $2.7 \%$ & 42 & $75.0 \%$ & 12 & $21.4 \%$ & 2 & $3.6 \%$ & & \\
\hline PARTICULAR FACILITIES & 462 & $22.3 \%$ & 405 & $87.7 \%$ & 54 & $11.7 \%$ & 2 & $0.4 \%$ & 1 & $0.2 \%$ \\
\hline Particular sports facilities & 266 & $12.8 \%$ & 248 & $93.2 \%$ & 16 & $6.0 \%$ & 2 & $0.8 \%$ & & \\
\hline Particular facilities (other) & 196 & $9.4 \%$ & 157 & $80.1 \%$ & 38 & $19.4 \%$ & & & 1 & $0.5 \%$ \\
\hline PERSONAL & 306 & $14.7 \%$ & 109 & $35.6 \%$ & 194 & $63.4 \%$ & 3 & $1.0 \%$ & & \\
\hline Personal-room & 46 & $2.2 \%$ & 16 & $34.8 \%$ & 30 & $65.2 \%$ & & & & \\
\hline Personal-home/housing & 91 & $4.4 \%$ & 33 & $36.3 \%$ & 58 & $63.7 \%$ & & & & \\
\hline Personal-work & 53 & $2.6 \%$ & 29 & $54.7 \%$ & 23 & $43.4 \%$ & 1 & $1.9 \%$ & & \\
\hline Personal-education & 116 & $5.6 \%$ & 31 & $26.7 \%$ & 83 & $71.6 \%$ & 2 & $1.7 \%$ & & \\
\hline MISCELLANEOUS & 67 & $3.2 \%$ & 52 & $77.6 \%$ & 14 & 20.98 & 1 & $1.5 \%$ & & \\
\hline Specific road/street & 12 & $0.6 \%$ & 12 & $100 \%$ & & & & & & \\
\hline World-scale & 2 & $0.1 \%$ & & & 2 & $100 \%$ & & & & \\
\hline Non-specific place & 9 & $0.4 \%$ & 9 & $100 \%$ & & & & & & \\
\hline Non-place/situation & 44 & $2.1 \%$ & 31 & $70.5 \%$ & 12 & $27.3 \%$ & 1 & $2.3 \%$ & & \\
\hline
\end{tabular}


Table 1

Attributes of 'other' shithole

Density and size

Role of history

Reputation and stereotypes

Violence, crime and terror

Lack of amenities

Environment and physical surroundings

Politico-economic

Demographic characteristics

Leisure and leisure facilities

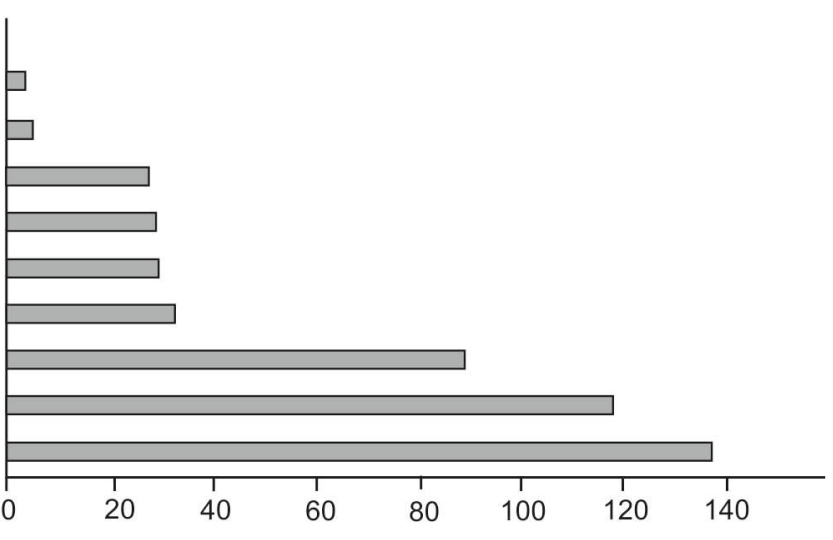

Number of tweets

Figure 2: attributes noted for 'other' shitholes (including, other area, other city, other region, other nation, and international scales). $\mathrm{N}=760$ but some tweets received multiples codes and others were uncoded because of a lack of codeable detail.

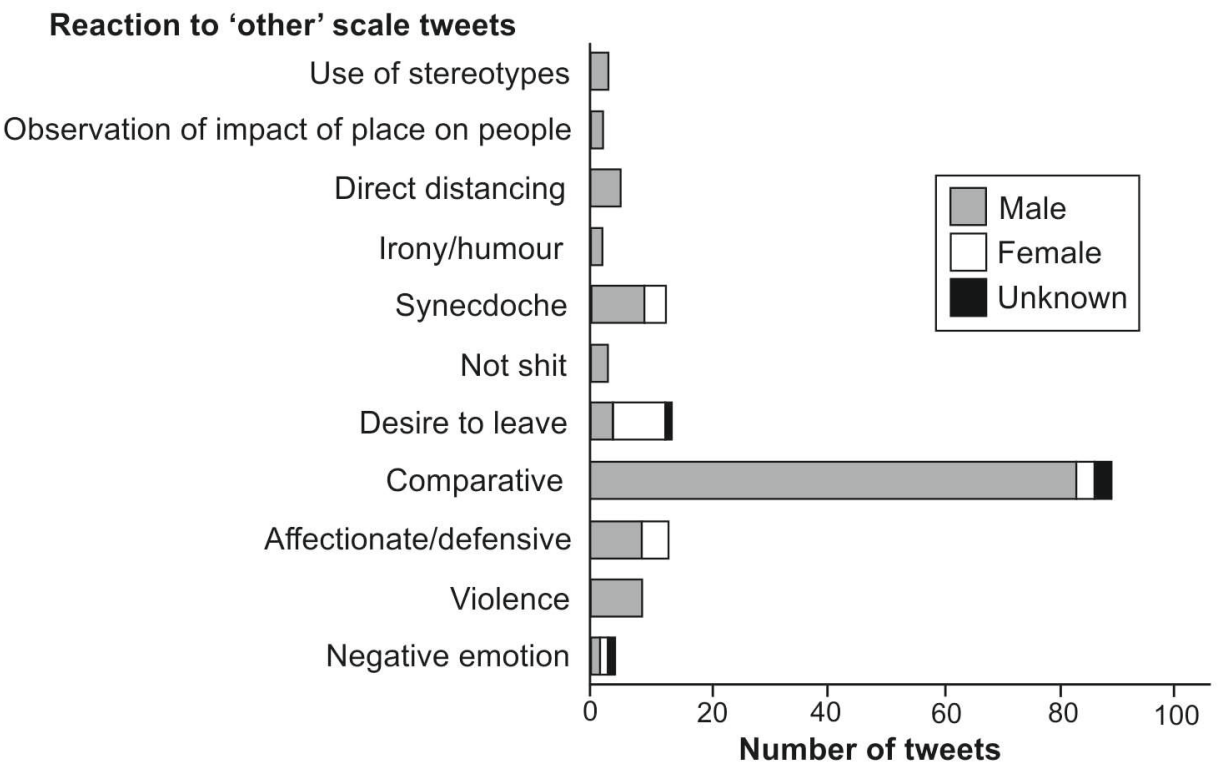

Figure 3 


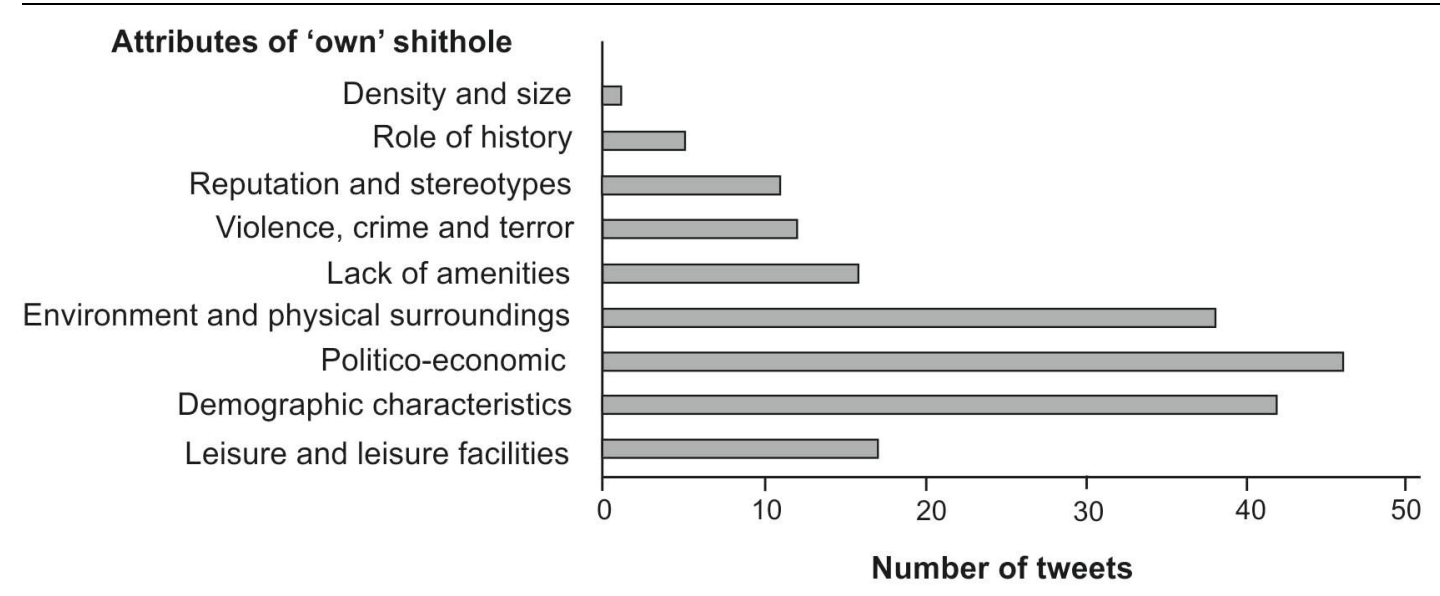

Figure 4: attributes noted for 'own' shitholes (including own area, own city, own region, and own nation). $\mathrm{N}=480$ but some tweets received multiples codes and others were uncoded because of a lack of codeable detail.

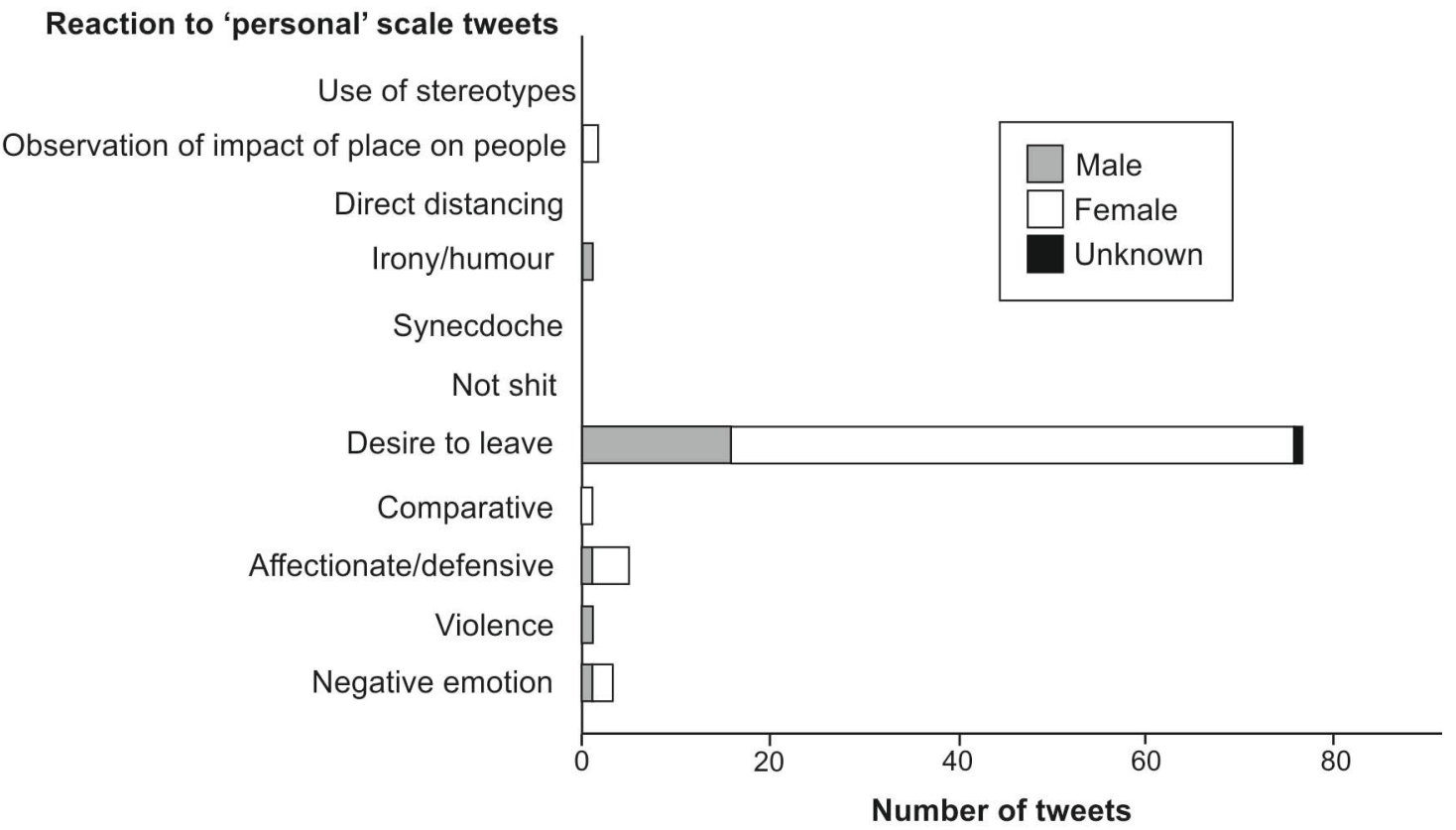

Figure 5 


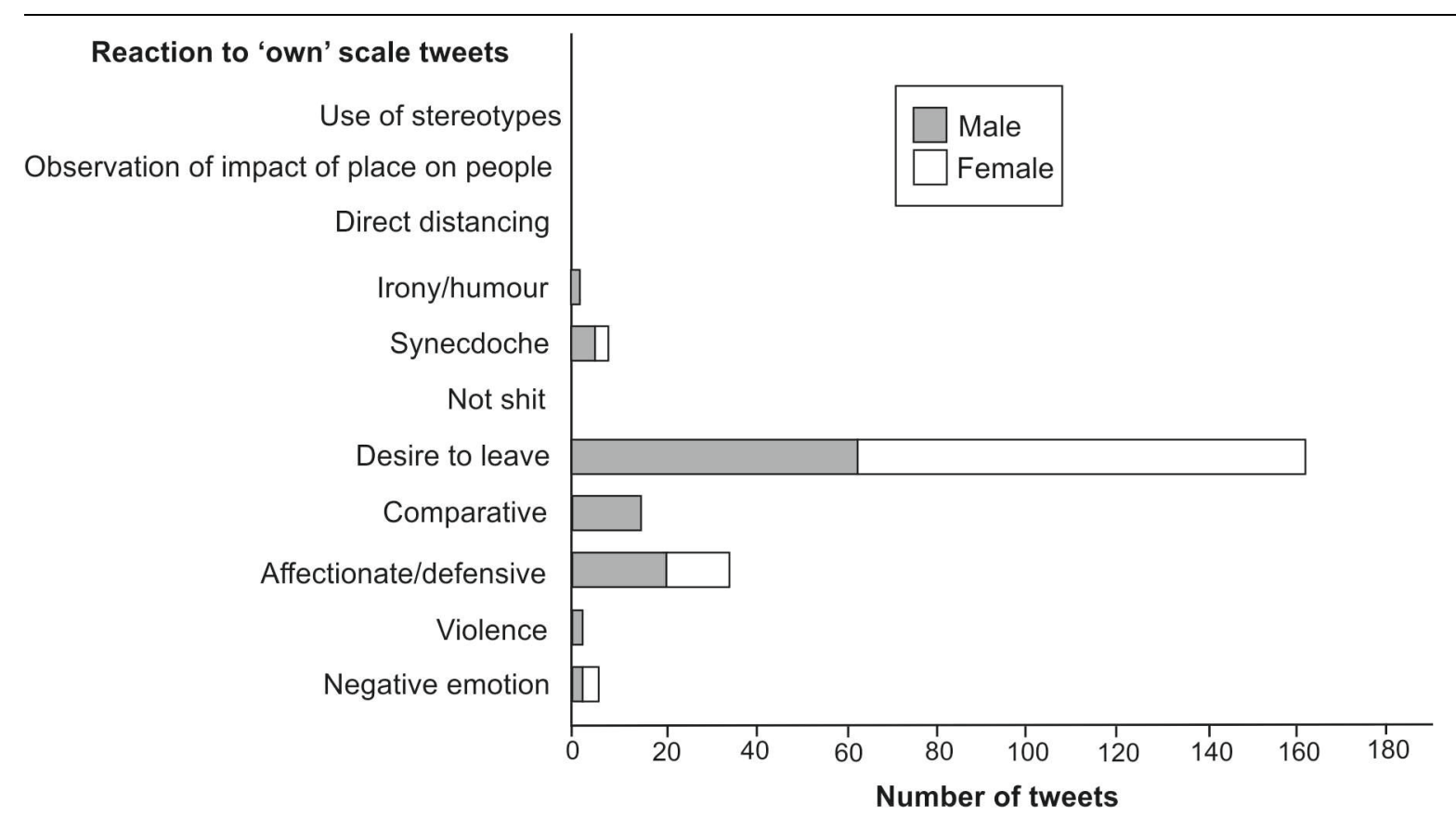

Figure 6 